\section{An Evaluation of Five Methods to Retreat Sprayed Mesquite ${ }^{1}$}

\author{
JON P. WEDDLE AND HENRY A. WRIGHT \\ Graduate Student and Associate Professor, \\ Range and Wildlife Management Department, \\ Texas Tech University, Lubbock.
}

\section{Highlight}

Based on mortality, chaining is the most economical method for retreating mesquite trees that are greater than 5 inches in diameter. For smaller trees, basal spray with diesel oil is most economical. Foliar spray with a mixture 2,4,5-T and Picloram is least economical.

\section{Resumen $^{2}$}

Varios ganaderos de Texas han aplicado herbicidas con avión para combatir

${ }^{1}$ Received October 20, 1969; accepted for publication February 21, 1970. Appreciation is extended to the PostMontgomery Estate for cooperation and financial assistance.

2 Por Donald L. Huss y E. Hernandez, al mezquite (Prosopis glandulosa var. glandulosa), sin embargo esta técnica solo es efectiva por tres o cinco años a - causa de sus rebrotes. El objetivo de este estudio fue comparar los siguientes cinco métodos para re-controlar dichos rebrotes: 1. Tirando una cadena con dos Bulldozers, 2) Aplicación foliar de Tordon 225, 3) Cortando con una chapoleadora, 4) Aplicación de dicscl al tronco después de cortado, y 5) Aplicación de diesel a la base de tronco. En base al porciento de plantas muestras, el método de cadena resultó mas económico para árboles de cinco o mas pulgadas de diámetro, para diámetros mas pequeños resultó ser la aplicación basal de diesel.

Dep. de Zoodecnia, ITESM, Monterrey, N. L., Mexico.
Many ranchers in Texas have used aerially applied herbicides to control mesquite (Prosopis glandulosa var. glandulosa). But past work shows that this method is effective only for three to five years (Fisher, 1952; Roach and Glendening, 1956; Fisher et al., 1959; Robison, 1963). Not only are results a problem but also standing dead growth restricts livestock movement and limits the ease with which livestock can be gathered.

It is estimated that 30 to $35 \mathrm{mil}$ lion acres of brush in Texas have been treated, but regrowth has reinfested thousands of these acres. Rechenthin et al. (1954) estimates that of the 35 million acres, only 15 million acres are still effectively controlled. Some of these controlled areas have been treated two or three times. Reinfestation is a constant problem on all treated rangeland. Considering these problems, what 
is the best method to retreat sprayed areas?

The purpose of this study was to evaluate and compare five methods of controlling basal sprouts from aerially sprayed mesquite. Foliar spray with a mixture of 2,4,5-T and Picloram, basal application of diesel oil, stump application of diesel oil, shredding, and chaining were compared. The effectiveness of these treatments on mortality in relation to tree size was compared on a cost basis.

\section{Methods and Procedures}

\section{Location and Description of Area}

This study was conducted on the Post-Montgomery Ranch in Lynn County, Texas, approximately 15 miles southeast of Tahoka. The study sites were aerially sprayed in 1963 and have an ample supply of mesquite trees with regrowth. Regrowth of these trees is also at the rccommended age for retrcatmont.

Relief of the study area is level to gently undulating. Elevation ranges from 3000 to $3300 \mathrm{ft}$. Geographically, this area is on the Southern High Plains known locally as the South Plains.

Average annual rainfall is approximately 19 inches. Distribution of precipitation varies widely from year to year, but almost $70 \%$ of the average annual precipitation falls during the growing season-May through September.

Soils of the area are classified in the Amarillo loam series of the Reddish Chestnut Great Soil Group. They are moderately deep permeable loams and sandy clay loams. The surface soil is a grayish-brown loam to sandy clay loam in texture and from 5 to 10 inches in thickness. The reddish-brown subsoil is a sandy clay loam, which is calcareous below 16 to 24 inches. Depth to the layer of calcium carbonate ranges from 32 to 54 inches.

Vegetation in the study area is typical of the southern mixed prairie. Climax vegetation is considered to be blue grama (Bouteloua gracilis), side-oats grama (Bouteloua curtipendula), tobosagrass (Hilaria mutica), and buffalograss (Buchloe dactyloides). The site still retains most of the original plants, but buffalograss, tobosagrass, and mesquite are now dominant.

\section{Design and Treatments}

Each treatment was tested on three basal size classes with at least 20 trees per size class: a) less than 3 inches in diameter, b) 3 to 5 inches in diameter, and c) over 5 inches in diameter. In the chaining treatment 40 trees per size class were marked since these trees could not be treated individually as in the other treatments. The trees for each treatment were chosen at random on a 5- to 10-acre area.

The following is a list of treatments and the dates of application:

1) Chaining twice in opposite directions-April 27, 1968.

2) Foliar spray application with Tordon 2253-June 27, 1968 (75 days following the initiation of leaf development).

3) Shredding-August 5, 1968.

4) Stump application of diesel oil-August 7, 1968.

5) Basal application of diesel oil -August 8, 1968.

Each of these treatments were applied at the time of the year when they were thought to be most effective. Results of the treatments were collected in August 1969. Each tree in the five treatments was individually inspected for sprouting at this time, and was recorded as either living or dead. These data were summarized to show the percent mortality in each treatment with respect to the various size classes. A Chisquare analysis was used to test for differences in mortality between treatments. In addition, cost per acre and cost per dead tree were calculated for each treatment.

\section{Results and Discussion}

\section{Treatments}

Foliar spray.-Tordon 225 killed $30 \%$ of the small trees, $5 \%$ of the

${ }^{3}$ Trade names are mentioned for identification only and do not imply endorsement by Texas Tech University. medium trees and none of the large trees. These results indicate that Tordon 225 is most effective on small trees $(\mathbf{P}<.05)$.

The poor kills on the large trees were partially due to poor coverage with the spray. Approximately one month after treatment, certain branches on the large trecs were fresh and green. This was not evident on small trees, indicating a more uniform coverage was attained on the small size class. This agrees with the findings of Fisher et al. (1959) and Hoffman and Ragsdale (1959) that ground equipment used for foliar applications is feasible only for mesquite less than $6 \mathrm{ft}$ tall.

Basal spray.-Basal application of diesel oil gave the highest mortality rates of the five treatments. Mortality was $85 \%$ for the small size class and $80 \%$ for the intcrmcdiate and large size classes (Table 1). The effect of basal spray was the same regardless of tree size.

The $85 \%$ kill obtained in the 1 to 3 inch size class indicates 1 pint of diesel per tree will give excellent results for small mesquite. Table 2 shows the average amount of diesel used per tree for each size class. The overall mortality rates for this treatment are slightly higher than the $79 \%$ obtained by Fisher et al. (1959), but this is probably not a significant difference.

Stump application.-The overall mortality percentage for stump application was less $(\mathrm{P}<.05)$ than that of the basal treatment (Table 1). This conflicts with the findings of Fisher et al. (1959). According to Fisher:

"The kill of brushy mesquite may be improved greatly with a considerable saving of oil if the topwood and lateral stems are cut back to the stump prior to oiling."

The reason mortality in stump application is slightly lower than basal spray may possibly be connected with the thoroughness of application. As shown in Table 2, less diesel was used for the stump treatment than for the basal treatment. 
Table 1. Mortality (\%) for follow-up treatments on sprayed mesquite.

\begin{tabular}{lcc}
\hline \hline \multicolumn{1}{c}{ Treatment } & $\begin{array}{c}\text { Size class } \\
\text { (basal diameter in inches) }\end{array}$ & Mortality $^{\mathbf{a}}$ \\
\hline Basal & $1-3$ & 85 \\
(Diesel oil) & $3-5$ & 80 \\
& $>5$ & 80 \\
Stump application & $1-3$ & 50 \\
(Diesel oil) & $3-5$ & 65 \\
& $>5$ & 80 \\
Foliar spray & $1-3$ & 30 \\
(Tordon 225) & $3-5$ & 5 \\
& $>5$ & 0 \\
Chained & $1-3$ & 0 \\
& $3-5$ & 12 \\
Shredded & $>5$ & 42 \\
& $1-3$ & 0 \\
& $3-5$ & 0 \\
\hline
\end{tabular}

a Based on 20 trees/size class, except for the chaining treatment which is based on 40 trees/size class.

This agrees with the findings of Fisher et al. (1959). Possibly, however, more diesel should have been uscd to increase the penetration of oil into the bud zone, especially for the two larger size classes.

Shredding.-Shredding was least effective of the five treatments. No mortality occurred among any of the size classes.

Chaining.-Chaining was effective on large trees $(\mathrm{P}<.05)$, but relatively ineffective on trees less than 5 inches in diameter (Table 1). Trees smaller than 5 inches in diameter were seldom uprooted; the chain tended to "ride over" these trees breaking stems off at ground level. Percentage kill decreased from $42 \%$ for large trees to $12 \%$ for the 3 to 5 -inch trees. No kills were obtained in the 1 to 3 -inch size class.

Table 2. Rates (pints/tree) of diesel for basal and stump treatments.

\begin{tabular}{cc}
\hline \hline Treatments & Rates \\
\hline Basal spray & \\
$1-3^{\mathrm{n}}$ & 1 \\
$3-5$ & 1.3 \\
$>5$ & 3.2 \\
Stump spray & \\
$1-3$ & 1 \\
$3-5$ & 1 \\
$>5$ & 2.4 \\
\hline
\end{tabular}

" Basal tree diameter in inches.
These kills agree with the findings of Fisher et al. (1959), but conflict with those reported by Reynolds and Tschirley (1963). Reynolds and Tschirley report that mesquite trees should be larger than 3 inches in diameter for chaining to be effective. Data from this study indicate that a 5-inch diameter should be the minimum limit. All trees recorded as dead, were completely uprooted with no evidence of resprouting. Trees that were only partially uprooted had prolific sprouting from the bud zone just below the soil surface.

\section{Cost of Treatments}

The approximate cost of each treatment was calculated on a per

Table 3. Estimated cost of treatments based on various tree densities per acre (includes labor and cost for diesel or chemical).

\begin{tabular}{lccc}
\hline \hline & \multicolumn{3}{c}{ Number of trees/acre } \\
\cline { 2 - 4 } \multicolumn{1}{c}{ Ireatment } & 50 & 80 & 110 \\
\hline $\begin{array}{l}\text { Basal spray } \\
\quad \text { Diesel oil) }\end{array}$ & $\$ 6.00$ & $\$ 9.00$ & $\$ 12.00$ \\
$\begin{array}{l}\text { Stump application } \\
\quad \text { (Diesel oil) }\end{array}$ & 7.00 & 11.00 & 14.00 \\
$\begin{array}{l}\text { Foliar spray } \\
\quad \text { (Tordon 225) }\end{array}$ & 11.00 & 19.00 & 27.00 \\
$\begin{array}{l}\text { Chaining } \\
\quad \text { (Two way) }\end{array}$ & 3.00 & 3.00 & 3.00 \\
Shredding & 2.00 & 2.50 & 3.00 \\
\hline
\end{tabular}

acre basis for various densities of mesquite (Table 3). Estimates are based on cost of chemical and labor, exclusive of equipment cost or rental.

Wages at $\$ 2.00$ per man hour were used in calculating labor cost for each treatment. The estimated man hours to apply diesel treatments varied from 2 to 4 hours per acre depending on the number of trees per acre; man hours to apply the foliar spray treatment varied from 2 to 6 hours per acre. Costs for chaining and shredding were based on local contract prices.

Cost of diesel was 15 cents per gallon. The amount of diesel used per tree for the diesel treatments was calculated from Table 2 . Since Tordon 225 is not sold at the present time, the cost was based on a suggested price of $\$ 26.80$ per gallon (Dow Chemical Company, Lubbock, Texas). To obtain the $1 / 2$ ae rate of 2,4,5-T and Picloram, $1 / 2$ gallon of chemical was used per 100 gallon of mixture. This amount of chemical would cost $\$ 13.40$ and will treat 100 trees, assuming that the trees vary evenly from small to large.

Cost of applying diesel varied with the method of application. The basal treatment was cheapest at 10 cents per tree for all densities, whereas the stump treatment cost 13 cents per tree. An estimated shredding cost of $\$ 2.00$ to $\$ 3.00$ per acre before applying diesel oil accounts for the three cent increase for stump treatment over basal 
Table 4. Estimated cost per dead tree in relation to tree size (inches basal diameter) assuming a medium density of 80 trees/acre.

\begin{tabular}{lccc}
\hline \hline & \multicolumn{3}{c}{ Size class } \\
\hline Treatment & $1-3$ & $3-5$ & $>5$ \\
\hline $\begin{array}{l}\text { Basal spray } \\
\quad \text { Diesel oil) }\end{array}$ & $\$ .11$ & $\$ .12$ & $\$ .17$ \\
$\begin{array}{l}\text { Stump } \\
\text { application } \\
\text { (Diesel oil) }\end{array}$ & .24 & .19 & .20
\end{tabular}

Foliar spray

(Tordon 225) $\quad .56 \quad 4.68$ No kill

Chaining

No kill $\quad .31 \quad .09$

treatment. These rates agree with those reported by Ames (1966), but are higher than those reported by Fisher et al. (1959). However, the cost stated by Fisher did not include labor at $\$ 2.00$ per man hour.

Based on the number of trees killed, basal spray is an economical method to kill small and medium size trees (Table 4). Costs ranged from 11 to 18 cents per dead tree, depending on the size and density of the mesquite. Stump application was more costly and less effective than the basal treatment. For trees greater than 5 inches in diameter, chaining was the most economical method. The cost for uprooting large trees ranged from 15 cents per dead tree for light densities to 7 cents for heavy densities.

Foliar spray on small mesquite trees was effective, but did not compare favorably with other treatments because of cost. Shredding was least effective with regard to mortality of the five treatments. However, because of the low cost per acre, periodic shredding may be effective as a temporary control for low-growing mesquite.

\section{Summary and Conclusions}

Five methods of mesquite control were evaluated as follow-up treatments on trees that had already received an aerial spray treatment. Each method was compared based on cost of treatments in relation to percent mortality. Costs varied with tree size, density, and method of application.

Based on mortality, chaining was most economical for trees greater than 5 inches in diameter. For smaller trees, basal spray was most economical. Stump application was slightly less effective than basal spray for killing trees and was slightly higher because of added cost for shredding. Foliar spray was least economical.

No attempt was made in this study to compute the total costs in- volved in mesquite control and subsequent range improvements. Costs presented only indicate those associated with killing the tree.

\section{Literature Cited}

Ames, C. R. 1966. Mesquite control on the Coronado National Forest. J. Range Manage. 19:148-150.

Fisher, C. E. 1952. The mesquite problem in the Southwest. J. Range Manage. 3:60-70.

Fisher, C. E., G. H. Meadors, R. Behrens, E. D. Robison, P. T. Marion, AND H. L. Morton. 1959. Control of mesquite on grazing lands. Texas Agr. Exp. Sta. Bull. 935.

Hoffman, G. O., and B. J. Ragsdale. 1959. Mesquite control. Texas Agr. Exp. Sta. Bull. MP-386.

Rechenthin, C. A., H. H. Bell, R. J. Pederson, AND D. B. Polk. 1964. Grassland restoration. Part II. Brush control. U.S. Dep. Agr., Soil Conserv. Serv., Temple, Texas.

Reynolds, H. G., ANd F. H. Tschirley. 1963. Mesquite control on southwestern rangeland. U.S. Dep. Agr. Bull. 421.

Roach, M. E., And G. E. Glendening. 1956. Response of velvet mesquite in southern Arizona to airplane spraying with 2,4,5-T. J. Range Manage. 9:70-73.

Robison, E. D. 1963. Chemical brush control in West Texas. Texas Agr. Prog. 9:3-5. 